\title{
ENGAGING YOUNG LEARNERS IN CONVERSATIONS: ONE WAY TO ASSESS THEIR SPEAKING SKILL
}

\author{
Diah Kurniati \\ diah.kurniati@umk.ac.id \\ Universitas Muria Kudus Indonesia \\ Moh. Achsan \\ Teladan Tutoring Agency, Kudus Indonesia
}

\begin{abstract}
As teachers, our job is not only teaching students, but also giving assessment as well. It means that teaching cannot be separated from assessing, including teaching to young learners. Assessment is defined as the gathering of information for a specific purpose (Linse, 2006). The assessment of young learners is very different from the assessment of older children and adult in several ways (Guddemi and Case , 2004). Moreover, they stated that in learning, young children must touch and manipulate objects, build and create many media, listen and act out stories and everyday roles, talk and sing, and move and play in various ways and environments. Since young learners' characteristics are different from adult, when teachers give assessment to them, they should pay attention to those things. As a result, the expression of what the children know and can do would be best served in ways other than traditional paper and pencil assessment (Guddemi and Case: 2004). This paper explores how to assess young learners' speaking skill by engaging them in conversations. It also describes the learners' psychological condition being assessed by using this activity. The subjects of this research were 7 students of Teladan Tutoring Agency which is located in Kudus, Central Java Province, Indonesia. The result of this research shows that by engaging the learners in a conversation during assessment, most of the students had positive psychological condition in which they felt confident, and brave to speak English (6 students). However two other students still felt nervous and afraid to make mistakes. Since engaging students in conversation in assessment is .an appropriate activity in assessing young learners, it is suggested that teachers who teach young learners use this activity when giving assessment to their young learner students. Keywords : young learners, speaking skill, assessment
\end{abstract}

\section{INTRODUCTION}

Assessing cannot be separated from teaching learning process. To know how far is a teacher's teaching instructional goal achieved, she or he should give assessment to the learners. In other words, assessment is needed to help teachers to make decisions about students' linguistic abilities, their placement in appropriate levels, and their achievement (Shaaban, 2014). According to Linse (2006), assessment is defined as gathering information for a specific purpose. Assessment can be done during teaching learning process. Assessing young learners should be different from assessing adults since young learners have different characteristics from adults. In this case, high quality assessments for young learners should be child-friendly, include developmentally appropriate activities and mirror quality instruction. In addition they should be 
individually and orally administered so as to provide immediate, diagnostic information to the teacher (Guddemi and Case, 2004). However, it seems that there are still a lot of teachers who teach young learners, more specifically who teach elementary school students in Kudus don't have sufficient awareness about this matter. When assessing their young learner students, they do it the same as when assessing adult learners. As a result those young learners feel nervous and afraid when they are being assessed. This paper discusses how to assess young learners' speaking skill by engaging them in conversation. It is also aimed to know students' psychological condition being assessed by using this activity.

\section{LITERATURE REVIEW}

\section{English Teaching in Primary School in Indonesia}

Preparing young people to learn English is very crucial since it will give positive impact on their awareness of foreign language which will later be used in their global communication. Although English language mastery is very needed in global communication, Indonesian government made a decision which is not In line with this statement above. Based on the Indonesian Educational Minister Regulation No. 67, 2013, English is not included as a compulsory subject for elementary school in Indonesia including elementary schools in Kudus regency. However, English is regarded as a local content. It means that it is a choice for the schools to teach the English subject or not to their students. As a consequence, in some primary schools in Kudus, English is taught from the fourth to the sixth grade. Meanwhile, in some other primary schools English is taught started from the first to the sixth level. There are also some schools which don't give the English subject to the students. This situation makes the English mastery of those primary school students greatly varied.

\section{Young Learners}

Many experts defined young learners differently. According to Philip, young learners are children from the first year of formal schooling (five/six years old to eleven or twelve year ages (Philip, 1993). Meanwhile Scott and Ytreberg (1990) divide children into two main groups. They are the five to seven years old and the eight to eleven years old considering mainly their ability to perceive the abstract and concrete. From this definition it can be concluded that young learners are children from five to twelve years old. When teaching to young learners, teachers should use different ways from teaching to adults. It is also the same as when teachers want to know young learners' language ability after learning process since they have different characteristics from adults.

\section{Characteristics of Young Learners}

Having well understanding about young learners' characteristics is a must for teachers especially those who teach young learners. It is because by understanding them well, teachers will be able to use appropriate techniques or activities in teaching or assessing the learners. According to Scott and Ytreberg (1990), young learners are enthusiastic and positive about learning. Moreover their own understanding comes through hands, eyes and ears. However, young learners also have a very short attention and concentration span. In line with this statement, Harmer (2007) also says that with their limited attention span, unless activities are extremely engaging, they can get easily bored, losing interest after ten minutes or so. Among other dominant characteristics of young learners is that they are keen to talk about themselves. They respond well to learning that uses themselves and their own lives as main topics in the classroom (Harmer, 2007). 


\section{Assessment for Young Learners}

Assessment is considered as one of an important aspect in all language setting. In addition, it is also one of important aspects in teaching and learning process. By giving assessment, teachers will get information about students' linguistic abilities as well as their achievement. Assessment can also be used to place them in appropriate levels (Shaaban,2001). Assessment is different from evaluation. Assessment refers to collecting information and making judgments on a learner's knowledge, whereas evaluation is used when collecting and interpreting information for making decisions about the effectiveness of an education program. (Brindley in Linse, 2006). Assessment is also defined as an on going process that encompasses much wider domain, such as when a student responds to a question, gives comments, or tries a new word or structure (Brown, 2003). When discussing assessment, there are two important things should be considered. They are validity and reliability. An assessment is considered to have validity if it measures the skill it is supposed to measure with a specific group of learners (Linse, 2006). For example, a valid assessment to assess if five year old learners can correctly pronounce the $/ \mathrm{m} /$ sound would be whether the children who have been taught the song Do You Know the Muffin Man? can accurately pronounce $/ \mathrm{m} /$ as they sing the words muffin and man. On the contrary, an invalid assessment of the $/ \mathrm{m} /$ sound would be whether they can write a letter when someone says a list of words with the $/ \mathrm{m} /$ sound. Beside validity, another important aspect in assessment is reliability. According to Linse (2006), an assessment tool is reliable if the results are consistent over a period of time. In other words, for a test to have reliability, the results should be consistent when different teachers administer the test and/or different teachers score them. The success of any assessment depends on the effective selection and use of appropriate tools and procedures as well as on the proper interpretation of students' performance (Shaaban, 2001).Since young learners have different characteristics from adults, when choosing assessment tools to young learners teachers should consider several points (Linse, 2006). First, teachers should make sure that the expectation of their young learners is reasonable. It means do not expect them to have better oral language skill in English than they possess in their native language. Second, wait time. It is the amount of time that the teacher waits for a learner to respond to a question, at least five seconds for a response. Finally, before children are given an English-language assessment, they need time to transition to English.

\section{Engaging Learners in Conversations as One Way to Assess Young Learners' Speaking Skill}

In learning English language, there are four skills to be mastered by young learners. One of them is speaking skill. There are several activities which can be used by teachers when assessing young learners' speaking skill, such as oral interview, portfolio assessment, role-play, doing monolog, and engaging students with conversation. However, in this research the writers only focus on assessing young learners by engaging them in conversations. As it is stated by Linse (2006), speaking skill can be assed by asking young learners questions and engaging them in conversations. In using this activity, first teacher and the learner sitting at a table, then the teacher shows the learner a picture of a family. After that the teacher starts conversation, and asks the learner about that picture. 


\section{METHOD}

This study belongs to best practice research which was conducted to discuss how to assess young learners' speaking skill by engaging those learners in conversations. It was also conducted to know students' psychological condition when young learners were being assessed by using this activity. Engaging in conversations means involving students in those conversations. The participant of this research were 7 (seven) students who join Teladan Tutoring Agency which is located in Jepang Village, Mejobo, Kudus, Central Java Province, Indonesia. They are 11 to 12 years old. Those students come from different elementary schools in Kudus and they have different language competencies as well. They get English subject one in a week for 60 minutes in that agency. When assessing those learners by using this activity, first of all the researcher and the young learner were sitting together at a table. Then, the researcher took a photo of a family consisting of a father, a mother, a daughter and a son. The researcher focused on "Family" as a topic to be discussed in the assessment since the students have got this material and they like to talk about their family. In this topic, the researcher wants to know students' ability in describing their family (especially in using simple present tense).

Then the researcher asked the student several questions related to that photo and after that the student was asked to talk about his/her family. The conversation happened naturally. The following is the list of questions.

1. Hi Anita. How are you to day?

2. Let's look at this picture. What picture is it?

3. How many persons are there in this family?

4. How many son do they have?

5. How many daughter do they have?

6. Do you have a picture of your family?

7. Please tell me about your family

8. Do you love your family?

This kind of assessment is rarely done in the learners' primary schools. In assessing the students in most elementary school in kudus, teachers usually just ask the students to do exercises written on students 'worksheet. That's why engaging students in conversations is a new activity for them. During the conversation, the researcher also observed the learners' psychological condition being assessed by using this activity. In assessing the students' speaking skill, the researcher used analytical scoring rubric which provides information broken down into different categories (comprehension, fluency, vocabulary, pronunciation, grammar)

\section{FINDINGS AND DISCUSSION}

As it is mentioned above that there were 7 (seven) students in this research, 3 female students and 4 male students who come from different schools in Kudus regency. Based on the result of the research it was found out that all the students could talk about their family members. When the teacher asked the students the following question :Do you have a picture of your family?

All the students directly showed the picture of their family from their mobile phones and they introduced their family one by one. They could use vocabulary related to family members although they still made mistakes in pronunciation and in grammar such as missing of to be and missing of s. The following is the result of students' speaking skill : 
Table 1. The result of students' speaking skill

\begin{tabular}{|c|c|c|c|c|c|c|c|}
\hline Student & $\begin{array}{c}\text { Compre } \\
\text { hension }\end{array}$ & Fluency & $\begin{array}{c}\text { Voca } \\
\text { bulary }\end{array}$ & $\begin{array}{c}\text { Pronun } \\
\text { ciation }\end{array}$ & Grammar & Score & \\
\hline SA & 3 & 2 & 3 & 2 & 4 & 14 & 70 \\
\hline SB & 4 & 3 & 4 & 3 & 3 & 17 & 85 \\
\hline SC & 3 & 3 & 4 & 3 & 3 & 16 & 80 \\
\hline SD & 3 & 3 & 4 & 4 & 3 & 17 & 85 \\
\hline SE & 3 & 3 & 3 & 3 & 4 & 16 & 80 \\
\hline SF & 4 & 3 & 3 & 3 & 3 & 15 & 75 \\
\hline SG & 4 & 3 & 3 & 3 & 3 & 14 & 70 \\
\hline & & & & & & & 78 \\
\hline
\end{tabular}

From the table above, it can be concluded that the highest score is 17 and the lowest score is 14.As it is explained previously that most of the students still had problems in pronunciation and in using simple present tense correctly. They were still confused when they should use $s$ or $e s$ or without s.

During the assessment, the researcher also did observation to know students' psychological condition being assessed using engagement activity. The following is the result of students' psychological condition.

Table 2. The Result of Students' Psychological Condition

\begin{tabular}{|c|l|}
\hline Student & \multicolumn{1}{|c|}{ Condition } \\
\hline SA & Nervous, \\
\hline SB & Good, Confident \\
\hline SC & Brave \\
\hline SD & Confident \\
\hline SE & Afraid, Nervous \\
\hline SF & Confident \\
\hline SG & Confident \\
\hline
\end{tabular}

Based on the table above, it can be concluded that being engaged in conversations during assessment made students feel relaxed as if they did not have any assessment. The conversations run smoothly and naturally and it made students more confident and they weren't afraid of making mistakes. However, two students still felt nervous (SA, SC) when they had to speak English.

\section{CONCLUSION AND SUGGESTION}

Since young learners have different characteristics from adults, when teaching English to those learners teachers should pay attention to several aspects. It also happens when teachers give assessment to them. Teachers should find appropriate assessment tools which are appropriate for young learners so that the assessment will be successful. The assessment used should be childfriendly, include developmentally appropriate activities and mirror quality instruction. One activity which was used by the writers was by engaging young learner $\mathrm{s}$ in conversations during assessment. Being engaged in conversation made young learners feel relax and had no burdened although they were being assessed. As a result, most of those young learners felt confident and 
brave enough to talk about their family in front of their teachers. Since engaging students in conversation in assessment is .an appropriate activity in assessing young learners, it is suggested that teachers who teach young learners use this activity when giving assessment to their young learner students.

\section{REFERENCES}

Brown, D.H. (2007). Teaching by Principles. New York: Pearson Education

Brown, D.H. (2003). Language Assessment. New York: Pearson Education

Guddemi, Marcy and BetsyJ.Case. (2004). Assessing Young Children. Pearson Education, Inc

Harmer, Jeremy. (1991). Principles of Language Learning and Teaching New Edition. New York: Longman

Linse, Caroline T. (2006). Practical English Language Teaching. New York: McNGraw-Hill Companies ,Inc

Phillips, S. (1993). .Oxford: Oxford University Press

Scoot, Wendy A and Lisbeth H Ytreber. (1998). Teaching English to Children. Harlow : Longman

Shaaban, Kaasim. Assessment of Young Learners. Forum Journal .Vol 39 No. 4, October 2001.page 16 